\title{
Comparison of the Efficacy of Nebulized and Intravenous Salbutamol in the Initial Treatment of Acute Severe Asthma
}

\author{
Amalia K.M. Katili, Hadiarto Mangunnegoro, Mohammad Farid, and Faisal Yunus
}

\begin{abstract}
Abstrak
Penelitian ini dilakukan untuk menentukan apakah salbutamol yang diberikan melalui nebuliser jet dengan cara inhalasi intermiten memberikan respons klinik jang lebih baik dibandingkan dengan pemberian intravena pada terapi tahap inisial asma akut berat. Penderita diobati secara random pada uji klinik buta tunggal dengan $5 \mu \mathrm{ggBB}$ salbutamol intravena atau inhalasi $0,15 \mathrm{mg} / \mathrm{kg} B B$ selama 10 menit. Peningkatan Arus Puncak Ekspirasi (APE) lebih besar pada kelompok inhalasi dibandingkan dengan kelompok intravena. Peningkatan pada kelompok inhalasi dari nilai awal sampai akhir jam pertama dan kedua setelah pengobatan adalah sebagai berikut $19,69 \pm 6,84 \%, 51,04 \pm 15,56 \%$ dan $56,64 \pm 15,93 \%$ nilai prediksi dengan $p<0,01$, dibandingkan $18,18 \pm 6,21 \%, 41,01 \pm$ $12,63 \%$ dan 50,83 $\pm 24,36 \%$ dengan $p<0,5$. Terdapat perbedaan bermakna antara kedua kelompok pada jain pertama $(p<0,1)$. Perbedaan bermakna juga terbukti dari perbaikan skor berdasarkan modifikasi dari cara British Thoracic Society dan Cochrane. Berat obstruksi awal, yakni APE t0, tidak mempunyai korelasi dengan lama sesak napas sebelum datang ke rumah sakit, tetapi mempunyai korelasi sedang dengan besar perubahan APE pada menit ke 45 pengobatan. Palpitasi, tremor dan sakit dada lebih menonjol pada jam pertama pemberian intravena, terutama pada menit ke 15 - 30 pengobatan. Satu kasus dari kelompok intravena tidak dapat meneruskan pengobatan karena sakit kepala dan muntah-muntah, sedangkan infus harus diperlambat pada satu kasus dengan ekstrasistole.
\end{abstract}

\begin{abstract}
This study was undertaken to determine if intermittent inhalation of salbutamol delivered by jet nebulizer provided better clinical response than intravenous salbutamol in the initial therapy of acute severe asthma. In a randomized single blind clinical trial, patients with acute severe asthma were given salbutamol either intravenously $5 \mu \mathrm{g} / \mathrm{kgBW}$ or by inhalation of $0.15 \mathrm{mg} / \mathrm{kg} B W$ for $10 \mathrm{minutes}$. A greater improvement in peak expiratory' flow rate (PEFR) was observed in the inhalation group compared to the intravenous group. The PEFR in the inhalation group was initially $19.69 \pm 6.84 \%$ of the predictive value, $51.04 \pm 15.56 \%$ one hour, and $56.64 \pm 15.93 \%$ two hours after treatment, with $p<0.01$, whereas in the group receiving intravenous salbutamol, the values were $18.18 \pm 6.21 \%, 41.05$ $\pm 12.63,50.83 \pm 24.36 \%$ respectively, with $p<0.05$. A statistically significant difference was found between both groups in the first hour after treatment was initiated $(p<0.01$ ). There was also a significant difference in the results assessed by modified British Thoracic Society and Cochrane scoring methods. No correlation was found between the severity of initial airway obstruction with the duration of dyspnea prior to admission, instead, moderate corellation was found between the severity of obstruction and the improvement of PEFR 45 minutes after initial treatment. Palpitation, tremor, and chest pain were more pronounced in intravenous group the first hour after treatment, particularly during the first 15 - 30 minutes. Symptoms of vomiting and headache were so severe in one patient given intraveous salbutamol that treatment had to be discontinued. In another patient, the rate of infusion had to be reduced because of the ectopic heartbeat it caused.
\end{abstract}

Keywords : Acute severe asthma, initial therapy, nebulization, salbutamol

Acute severe asthma is a life threatening situation that demands adequate and rapid therapeutic intervention. Simple assessment of the severity of the attack coupled to the response to the initial treatment will serve to identify early a high risk group of asthmatic patients in which the usual emergency room therapeutic modalities will often prove ineffective. ${ }^{1}$ The immedi-

Department of Pulmonology, Faculty of Medicine, University of Indonesia, Persahabatan Hospital, Jakarta, Indonesia ate relief of symptoms and the magnitude of the initial improvement will determine further therapy and prognosis.

Although the route of administration may vary, B2agonists are still widely used as first line drugs in the initial therapy for acute asthma. Several studjes have compared inhalation with intravenous administration of B2-agonists in patients with acute severe asthma. Both methods have often been proved to be equally effective in relieving bronchoconstriction, but inhala- 
tion therapy has sometimes been found to be more favorable regarding side effects. Several studies have showed that even though the peak response did not differ significantly, there was a tendency for earlier occurence of bronchodilatation after inhalation therapy $^{2}$ and a slower decline in effect, ${ }^{3}$ whereas intravenous salbutamol was found to increase $\mathrm{PaO}_{22}$ and better affect paradoxical pulse. ${ }^{4}$ A multicenter study organized by the Swedish Society of Chest Medicine (SSCM) provided definitive evidence of superiority of inhaled salbutamol in the treatment of acute episode. ${ }^{5}$

The principal aim of this study was to determine whether nebulized inhalation of salbutamol was more effective in treating severe asthmatic attack, particularly within the initial phase, when compared to an intravenous bolus infusion of the same drug. An additional purpose was to determine the difference in side effects and whether additional medication could improve the results.

\section{METHODS}

This study is a randomized single blind clinical trial of short term responses to compare nebulized to intravenous salbutamol. The trial was carried out at the Emergency Unit of the Persahabatan Hospital in Jakarta, from August 1991 to May 1992.

One hundred patients aged 15 - 45 years were included in this study. The number was sufficiently large to enable statistically reliable conclusions to be drawn. All were admitted to the respiratory emergency room because of acute severe asthma. These patients were clinically defined as having an index of $\geq 4$ according to a modified British Thoracic Society (BTS) and Cochrane scoring methods (table 1). ${ }^{6,7}$ The Peak Expiratory Flow Rate (PEFR) value on admission was less than $200 \mathrm{l} / \mathrm{min}$. or less than $40 \%$ of the predictive value. ${ }^{7}$ The patients excluded were those who could not be evaluated by a peak flow meter, or those with a history of cardiovascular, liver, or renal diseases, diabetes mellitus, hiperthyroidism, pregnancy, or nonasthmatic chronic respiratory insufficiency. Patients receiving corticosteroids, oral or intravenous B2agonists less than four hours prior to admission, or aminophylline less than six hours before admission were also excluded. Those with a PEFR value of less than $15 \%$ of the predictive value 30 minutes after initial treatment or suffering severe side effects were also excluded from this study.

Subjects fulfilling the criteria were divided into 2 groups (figure 1$)$, group one $(n=48)$ was treated with inhalation of a single dose of salbutamol, while group two $(n=51)$ was given a bolus infusion of salbutamol. The PEFR, measured by a Mini Wright Peak Flow Meter (Airmed, Clement Clarke International Ltd., London, England), pulse rate, and systolic and diastolic blood pressures measured by a sphygmomanometer were variables recorded prior to the initial treatment and every 15 minutes thereafter for 2 hours. The best of 3 PEFR values for each patient was calibrated to normal Indonesian predicted values obtained by the Indonesian Pneumobile Project. Each patient was asked to note the presence or absence of side effects, such as tremor, palpitation, nausea, headache, or other symptoms.

Tabel 1. Assessment of severity

\begin{tabular}{|c|c|c|}
\hline Signs and Symptoms & Score 0 & Score 1 \\
\hline $\begin{array}{l}\text { 1. Unable to complete sentences in one } \\
\text { breath }\end{array}$ & No & Yes \\
\hline $\begin{array}{l}\text { 2. Using accessory muscles, "tracheal tug", } \\
\text { intercostal retraction }\end{array}$ & No & Yes \\
\hline 3. Wheezing & No & Yes \\
\hline 4. Respiratory rate (breaths/min.) & $<20$ & $\geq 25$ \\
\hline 5. Heart rate persistently (beat/min.) & $<120$ & $\geq 120$ \\
\hline $\begin{array}{l}\text { 6. Palpable change of an inspiratory fall } \\
\text { in blood pressure of } \geq 10 \mathrm{mmHg}\end{array}$ & No & Yes \\
\hline $\begin{array}{l}\text { 7. Peak expiratory flow rate ( } 1 / \mathrm{min} \text {.) } \\
\text { (in \% predicted) }\end{array}$ & $\begin{array}{l}>200 \\
>40 \%\end{array}$ & $\begin{array}{l}\leq 200 \\
\leq 40 \%\end{array}$ \\
\hline
\end{tabular}

(Modified from Refs. 6 and 7)

The dose for inhalation was $0.15 \mathrm{mg} / \mathrm{kgBW}$ of $5 \mathrm{mg} / \mathrm{ml}$ salbutamol solution diluted with $2 \mathrm{ml} 0.9 \% \mathrm{NaCl}$ solution in a jet nebulizer (Pari-Master, Paul Ritzau, PariWerk $\mathrm{GmbH}$ ). The compressed air nebulizer produced a mass median particle with a diameter of $9.7 \mu$ and an intrapulmonary deposition of $30-40 \%^{8}$ over a period of $7 \pm 4$ minutes of nebulization time. ${ }^{5}$ Nebulization was interrupted during expiration. The procedure was continued until the nebulizer was dry, in order to reduce wastage of the nebulised solution. ${ }^{9}$ Subjects in group two were given $5 \mu \mathrm{g} / \mathrm{kgBW} / \mathrm{min}$ salbutamol, diluted in $100 \mathrm{ml}$ of $0.9 \% \mathrm{NaCl}$ solution, intravenously over a period of 10 minutes. ${ }^{5,10}$ Aminophylline 5-6 $\mathrm{mg} / \mathrm{kgBW}$, diluted in $20 \mathrm{ml}$ of $5 \%$ glucose solution, was given 60 minutes after the administration of salbutamol. This dose was reduced to half if the patient have taken oral theophylline during the last 24 hours. All patients were given $200 \mathrm{mg}$ intravenous hydrocortisone and continous oxygen $6-8 \mathrm{l} / \mathrm{min}$ by nasal canule at the start. ${ }^{10}$ The study was completed in 120 minutes. Final evaluation was made on the condition of 
asthmatic symptoms, whether it was improved, worsened or remained unchanged, and whether the patient needed additional treatment with bronchodilators or antibiotics for respiratory tract infection.

Nonparametric statistics, Chi-square and Mann-Whitney analysis for unpaired data, were used to analyze the changes in side effects and score of the asthmatic attack. Paired $\mathrm{Z}$ test was applied for comparing pulse rate, respiratory frequency, and PEFR (in $1 / \mathrm{min}$. and in
$\%$ of the predictive value) in patients of the same group. Comparison of changes in symptoms between the two groups was made using an analysis of variance with 3 variables. Measurements at a given time were compared by using non paired $\mathrm{Z}$ test. KolmogorovSmirnov test was used to evaluate similarities in the duration of dyspnea prior to admission and the frequency of attacks between the two groups. Correlation analysis was used in evaluating two variables quantitatively.

\section{STUDY PROTOCOL}

Treatment

Salb iv $5 \mu \mathrm{g} / \mathrm{KgBW}$
(in $\mathrm{NaCl} 0.9 \% 100 \mathrm{ml}$ )
$+\mathrm{NaCl}$ inhal $0.9 \% 2 \mathrm{ml}$
Hydrocortisone $200 \mathrm{mg}$ iv
$\mathrm{x}-\mathrm{x}-\mathrm{Aminophylline} \mathrm{bolus}$
$\mathrm{x}-\mathrm{x}$ - $\mathrm{x}$ -

Salb inh $0.15 \mathrm{mg} / \mathrm{KgBW}$

(in $\mathrm{NaCl} 0.9 \% 2 \mathrm{ml}$ )

$+\mathrm{NaCl}$ inhal iv $100 \mathrm{ml}$

Group H Hydrocortisone $200 \mathrm{mg}$ iv

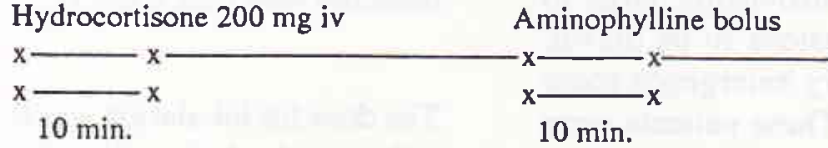

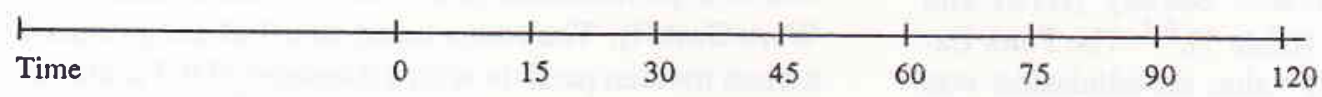

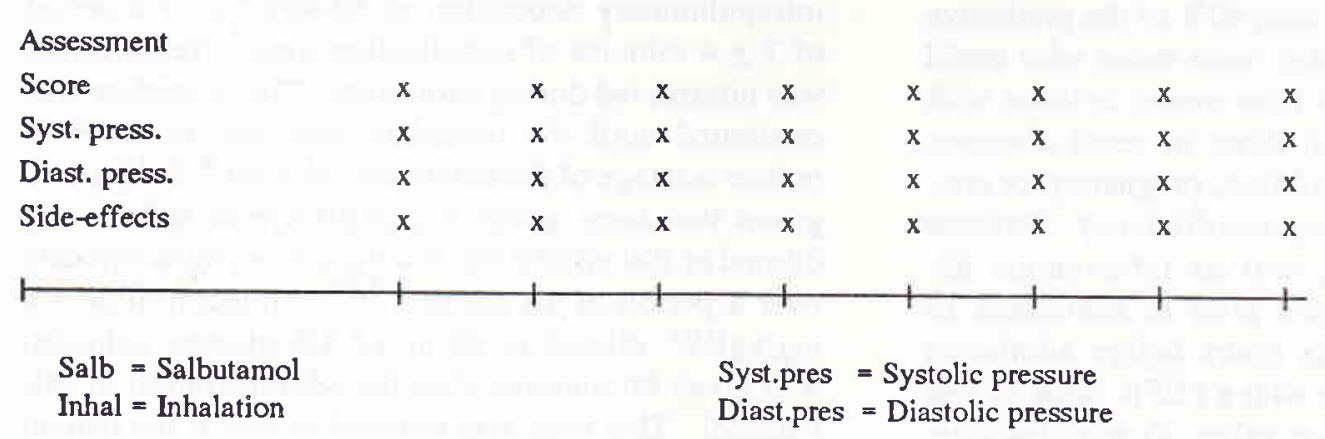

Figure 1. Treatment protocol for Inhalation and Intravenous Groups 


\section{RESULTS}

Except for the duration of breathlessness prior to admission, no significant difference in characteristics between patients in the two study groups was found $(p<0.05)$. The occurence of respiratory tract infections was also proportional in both groups (table 2). Differences in the severity of the 7 variables assessed were apparent at minute- 15 and continued until minute-105 after treatment (table 3). Patients receiving intravenous salbutamol were slower to respond than those receiving inhalation (figure 2 ).
In those receiving inhalation, the inability to complete a sentence disappeared after 30 minutes of treatment, while in the intravenous group it took 60 minutes. There was a significant difference in the number of patients using the accessory muscles for respiration at minute- $60,12 \%$ vs $2.08 \%$ cases ( $p<0.05$ ). No significant change in the incidence of paradoxical pulse was found between both groups. There was still a significant difference in the number of patients wheezing at minute- $120(\mathrm{p}<0.01)$.

Tabel 2. Patient characteristics on admission to the study (mean \pm SD or percentage of patients)

\begin{tabular}{|c|c|c|c|}
\hline & $\begin{array}{l}\text { Inhalation } \\
\quad(n=48)\end{array}$ & $\begin{array}{l}\text { Intraveous } \\
\quad(n=50)\end{array}$ & $\mathrm{p}$ \\
\hline $\begin{array}{l}\text { Age (years) } \\
\text { Males / Fermales } \\
\text { Height (cm) } \\
\text { Weight }(\mathrm{kg})\end{array}$ & $\begin{array}{l}30.08 \pm 8.31 \\
38 \% / 62 \% \\
155.06 \pm 7.23 \\
49.55 \pm 8.62\end{array}$ & $\begin{array}{l}29.12 \pm 7.47 \\
40 \% / 60 \% \\
156.79 \pm 7.62 \\
50.65 \pm 9.16\end{array}$ & $\begin{array}{l}>0.05 \\
>0.05 \\
>0.05 \\
>0.05\end{array}$ \\
\hline $\begin{array}{l}\text { History of chronic asthr } \\
0-10 \\
11-20 \\
21-30\end{array}$ & $\begin{array}{l}34(70.8 \%) \\
12 \\
2\end{array}$ & $\begin{array}{l}32(64 \%) \\
13 \\
3\end{array}$ & $>0.05$ \\
\hline $\begin{array}{l}\text { Frequency of attack } \\
0 \\
0-10 \\
11-20 \\
21-30\end{array}$ & $\begin{array}{l}16(33.33 \%) \\
26 \\
0 \\
6\end{array}$ & $\begin{array}{l}21(42 \%) \\
24(48 \%) \\
3 \\
2\end{array}$ & $>0.05$ \\
\hline $\begin{array}{l}\text { Duration of dyspnea } \\
0-10 \\
11-20 \\
21-30 \\
>30\end{array}$ & $\begin{array}{l}32(66.66 \%) \\
16(33.33 \%) \\
0 \\
0\end{array}$ & $\begin{array}{l}26(52 \%) \\
13(26 \%) \\
6(22 \%) \\
5\end{array}$ & $\begin{array}{l}<0.05 \\
\text { Significant }\end{array}$ \\
\hline $\begin{array}{l}\text { Signs and symptoms of } \\
\text { Yes } \\
\text { No }\end{array}$ & $\begin{array}{l}\text { ection } \\
12(25.42 \%) \\
36(75 \%)\end{array}$ & $\begin{array}{l}18(36 \%) \\
32(64 \%)\end{array}$ & $>0.05$ \\
\hline $\begin{array}{l}\text { Pulse rate (beats/min) } \\
\text { PEFR l/min } \\
\text { PEFR \% of pred. } \\
\text { Syst.pres. (mmHg) } \\
\text { Diast.pres (mmHg) } \\
\text { Score (Med-range) }\end{array}$ & $\begin{array}{r}109.16 \pm 11.27 \\
89.79 \pm 27.17 \\
19.69 \pm 6.84 \\
132.92 \pm 19.35 \\
87.71 \pm 11.89 \\
6(2468)\end{array}$ & $\begin{array}{r}108.16 \pm 13.08 \\
82.40 \pm 28.68 \\
18.18 \pm 6.21 \\
126.20 \pm 14.69 \\
85.00 \pm 11.47 \\
6(2383)\end{array}$ & $\begin{array}{l}>0.05 \\
>0.05 \\
>0.05 \\
>0.05 \\
>0.05\end{array}$ \\
\hline
\end{tabular}

Syst.pres. = Systolic pressure

Diast.pres. $=$ Diastolic pressure 
Tabel 3. Relieving of the attack over the observation minutes in the two treatment groups (mean or percentage of patients)

\begin{tabular}{|c|c|c|c|c|c|c|c|}
\hline Parameters & $\begin{array}{l}0 \\
\mathrm{~V} \\
\mathrm{H} \\
\mathrm{p}\end{array}$ & $\begin{array}{r}15 \\
\mathrm{~V} \\
\mathrm{H} \\
\mathrm{P}\end{array}$ & $\begin{array}{l}30 \\
\mathrm{~V} \\
\mathrm{H} \\
\mathrm{p}\end{array}$ & $\begin{array}{c}45 \\
\mathrm{~V} \\
\mathrm{H} \\
\mathrm{P}\end{array}$ & $\begin{array}{c}60 \\
\mathrm{~V} \\
\mathrm{H} \\
\mathrm{p}\end{array}$ & $\begin{array}{l}90 \\
\mathrm{~V} \\
\mathrm{H} \\
\mathrm{p}\end{array}$ & $\begin{array}{r}120 \\
\mathrm{~V} \\
\mathrm{H} \\
\mathrm{p}\end{array}$ \\
\hline $\begin{array}{l}\text { 1. Unable to complete } \\
\text { sentences in } \\
\text { one breath (\%) }\end{array}$ & $\begin{array}{l}88 \\
91.67 \\
>0.05\end{array}$ & $\begin{array}{l}40 \\
14.58 \\
>0.025\end{array}$ & $\begin{array}{l}8 \\
0\end{array}$ & $\begin{array}{l}2 \\
0\end{array}$ & $\begin{array}{l}0 \\
0\end{array}$ & - & - \\
\hline $\begin{array}{l}\text { 2. Using accesorry } \\
\text { muscle (\%) }\end{array}$ & $\begin{array}{l}100 \\
100 \\
>0.05\end{array}$ & $\begin{array}{l}74 \\
39.58 \\
<0.002\end{array}$ & $\begin{array}{l}32 \\
8.33 \\
<0.01\end{array}$ & $\begin{array}{l}22 \\
2.08 \\
<0.01\end{array}$ & $\begin{array}{l}12 \\
2.08 \\
<0.05\end{array}$ & $\begin{aligned} & 6 \\
& 0 \\
> & 0.05\end{aligned}$ & $\begin{array}{l}\quad 4 \\
2.08 \\
>0.05\end{array}$ \\
\hline 3. Wheezing (\%) & $\begin{array}{l}100 \\
100 \\
>0.05\end{array}$ & $\begin{array}{l}84 \\
58.33 \\
<0.01\end{array}$ & $\begin{array}{l}66 \\
35.42 \\
<0.01\end{array}$ & $\begin{array}{l}62 \\
16.66 \\
<0.01\end{array}$ & $\begin{array}{l}54 \\
10.42 \\
<0.001\end{array}$ & $\begin{array}{l}36 \\
4.17 \\
<0.001\end{array}$ & $\begin{array}{l}20 \\
4.17 \\
<0.05\end{array}$ \\
\hline 4. Paradoxical Pulse (\%) & $\begin{aligned} & 70 \\
& 75 \\
> & 0.05\end{aligned}$ & $\begin{array}{l}18 \\
6.25 \\
>0.05\end{array}$ & $\begin{array}{l}12 \\
0 \\
>0.05\end{array}$ & $\begin{array}{c}4 \\
0 \\
>0.05\end{array}$ & - & - & - \\
\hline $\begin{array}{l}\text { 5. Respiratory } \\
\text { rate (breaths/min.) }\end{array}$ & $\begin{array}{l}28.76 \\
29.81 \\
>0.05\end{array}$ & $\begin{array}{l}26.74 \\
25.83 \\
>0.05\end{array}$ & $\begin{array}{l}24.84 \\
23.87 \\
>0.05\end{array}$ & $\begin{array}{l}24.4 \\
22.96 \\
>0.05\end{array}$ & $\begin{array}{l}23.28 \\
22.38 \\
>0.05\end{array}$ & $\begin{array}{l}22.52 \\
21.71 \\
>0.05\end{array}$ & $\begin{array}{l}21.9 \\
21.2 \\
>0.05\end{array}$ \\
\hline & \multicolumn{5}{|c|}{$\begin{array}{l}V t(0-60): p<0.05 \\
H t(0-60): p<0.05\end{array}$} & \multicolumn{2}{|c|}{$\begin{array}{l}V t(60-120): p>0.05 \\
H t(60-120): p>0.05\end{array}$} \\
\hline \multirow[t]{2}{*}{$\begin{array}{l}\text { 6. Pulse rate } \\
\text { (beat/min.) }\end{array}$} & $\begin{array}{l}108.16 \\
109.17 \\
>0.05\end{array}$ & $\begin{array}{l}127.04 \\
117.17 \\
<0.01\end{array}$ & $\begin{array}{l}117.2 \\
109.87 \\
<0.01\end{array}$ & $\begin{array}{l}109.6 \\
104.9 \\
>0.05\end{array}$ & $\begin{array}{l}105.9 \\
100.9 \\
>0.05\end{array}$ & $\begin{array}{l}97.27 \\
96.88 \\
>0.05\end{array}$ & $\begin{array}{l}97.2 \\
92.8 \\
>0.05\end{array}$ \\
\hline & \multicolumn{5}{|c|}{$\begin{array}{l}V t(0-60): p>0.05 \\
H t(0-60): p>0.05\end{array}$} & \multicolumn{2}{|c|}{$\begin{array}{l}V t(60-120): p<0.05 \\
H t(60-120): p>0.05\end{array}$} \\
\hline \multirow[t]{2}{*}{ 7. PEFR (\% of predicted) } & $\begin{array}{l}18.18 \\
19.69 \\
>0.05\end{array}$ & $\begin{array}{l}34.18 \\
39.82 \\
>0.05\end{array}$ & $\begin{array}{l}37.53 \\
45.59 \\
<0.01\end{array}$ & $\begin{array}{l}39.62 \\
49.79 \\
<0.01\end{array}$ & $\begin{array}{l}41.05 \\
51.04 \\
<0.01\end{array}$ & $\begin{array}{l}46.61 \\
54.42 \\
<0.05\end{array}$ & $\begin{array}{c}50.8 \\
56.6 \\
>0.05\end{array}$ \\
\hline & \multicolumn{6}{|c|}{$\begin{aligned} V: F & =113.7 \\
d f & =2 ; 149.05 \\
p & <0.01\end{aligned}$} & $\begin{array}{l}=118.5 \\
=2 ; 143 \\
<0.05\end{array}$ \\
\hline 8. Score of improvement & $\begin{aligned} & 6 \\
& 6 \\
> & 0.05\end{aligned}$ & $\begin{aligned} & 4.5 \\
& 3 \\
< & 0.01\end{aligned}$ & $\begin{aligned} & 3 \\
& 2 \\
< & 0.05\end{aligned}$ & $\begin{aligned} & 2.5 \\
1 & < \\
< & 0.01\end{aligned}$ & $\begin{aligned} & 2 \\
& 1 \\
&< 0.01\end{aligned}$ & $\begin{aligned} & 1 \\
& 0 \\
< & 0.05\end{aligned}$ & $\begin{aligned} & 0 \\
& 0 \\
> & 0.05\end{aligned}$ \\
\hline
\end{tabular}

p $>0.05$ : not significant

$\mathrm{V}=$ Intravenous group $p<0.05$ : significant

$\mathrm{H}=$ Inhalation group $\mathrm{p}<0.01$ : very significant 


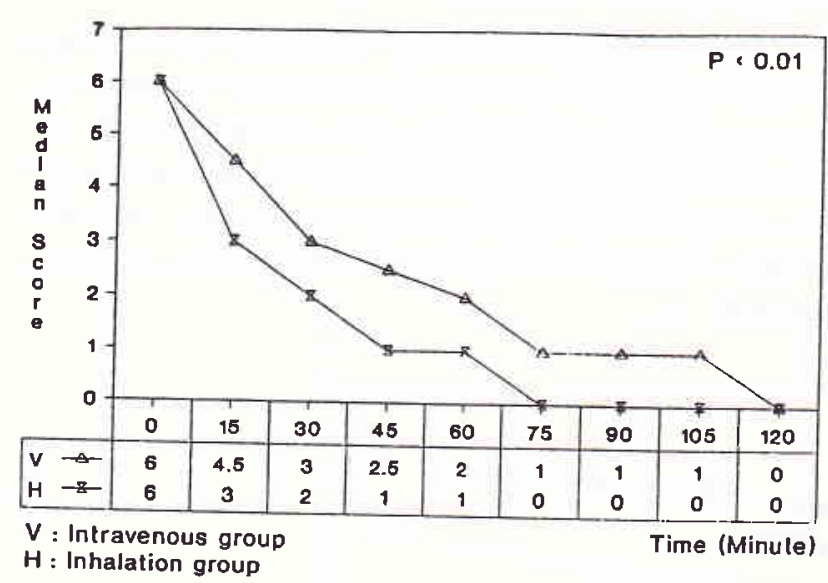

Figure 2. Improvement of Score in Inhalation and Intravenous Group

\section{Systemic Effects}

No significant difference in blood pressure was observed between the 2 groups ( $p>0.05$ ) during the duration of the study. Although the mean diastolic and systolic pressures were lower in minute-60 and minute- 120 when compared with minute- 0 , the difference was not statistically significant. The difference in pulse rates between two treatment groups were significant at minutes- 15,30 , and 75 , with the mean pulse rates higher for the intravenous group; 127 \pm 13.2 vs $117.2 \pm 14.3$ ( $p<0.01), 117.2 \pm 11.8$ vs 109.9 $\pm 12(\mathrm{p}<0.01)$, and $103.9 \pm 17.9$ vs $97.5 \pm 11.6$ beats/min. $(p<0.05)$, respectively (table 3$)$. The increase occurred in minute-15, 19 beats compared to 8 beats/min., with the difference becoming statistically significant in minutes- 15 and 30 . The mean pulse rates of both groups returned to the pre-treatment values in minute- 45 .

More complaints of tremor (figure 3 ) and palpitation (figure 4) were observed among patients in the intravenous group. The peak difference was seen in minute-30. One patient with complaints of vomiting and headaches 5 minutes after initial treatment had to be withdrawn from the trial. The infusion rate had to be reduced in one patient, when ectopic heartbeats occurred 5 minutes after initial treatment.

\section{The Effects on Lung Function}

There was a significant improvement in lung function in both groups (figure 5). A greater increase in PEFR was observed in the inhalation group, with a significant increase apparent in minute-15 $(p<0.05)$. This increase peaked in minute-45 $(p<0.01)$ and lasted until minute-90 $(\mathrm{p}<0.05)$. The average PEFR rose from $84.4 \pm 28.68 \mathrm{l} / \mathrm{min} .(18.18 \pm 6.2 \%)$ to $185.25 \pm 56.03$ $1 / \mathrm{min}$. ( $41.05 \pm 12.63 \%$ of the predictive value) in minute- 60 , and to $216.3 \pm 57.08 \mathrm{l} / \mathrm{min}$. $(50.83 \pm$ $24.36 \%$ of the predictive value) in minute-120 after administration of intravenous salbutamol $(p<0.01)$. In the inhalation group, the PEFR improved from 89.79 $\pm 27.17 \mathrm{l} / \mathrm{min} .(19.69 \pm 8.84 \%)$ to $234.79 \pm 67.85$ $1 / \mathrm{min}$. ( $51.04 \pm 15.56 \%$ of the predictive value) in minute- 60 and to $260.73 \pm 70.5 \mathrm{l} / \mathrm{min}$. $(56.64 \pm 15.9 \%$ of the predictive value) in minute- $120(\mathrm{p}<0.05)$. The greatest increase in both groups was achieved in minute-60 ( $p<0.01$ ), with inhalation achieving more significant increase when compared to those recieving intravenous salbutamol $(p<0.01)$. There was also a significant difference in therespiration rate $(p<0.05)$.

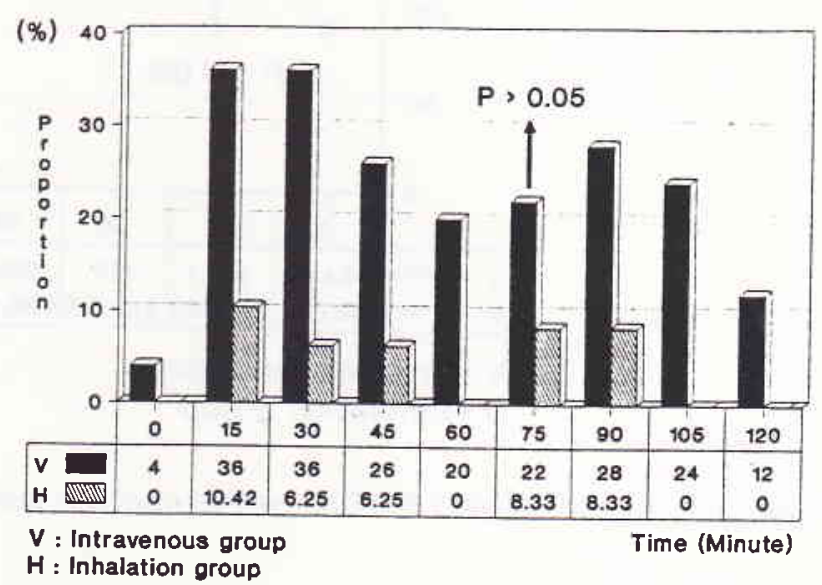

Figure 3. Distribution of patients with tremor

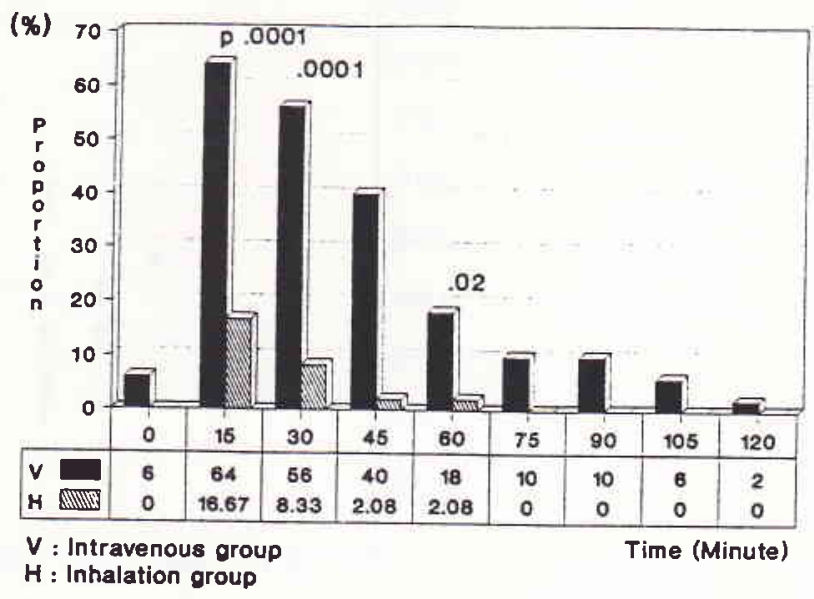

Figure 4. Distribution of patients with palpiration

The asthma index assessed in minute- 15 and 105minute was significantly different for both groups, 
with the inhalation group showing an earlier decline in symptoms (figure 2). No relationship was found between the duration of breathlessness and the severity of airway obstruction (PEFR) on admission to the study ( $r=0.09$ ). In the group receiving intravenous salbutamol, the improvement in the average PEFR of patients experiencing dyspnea for more than 30 hours prior to admission was greater than those of more than 10 hours. The initial severity of airway obstruction was moderately correlated with the magnitude of bronchospasm relief at minute-45 $(r=0.544)$, although the change was slightly lower in patients of both groups with more severe initial obstruction (table 4; figure 6).

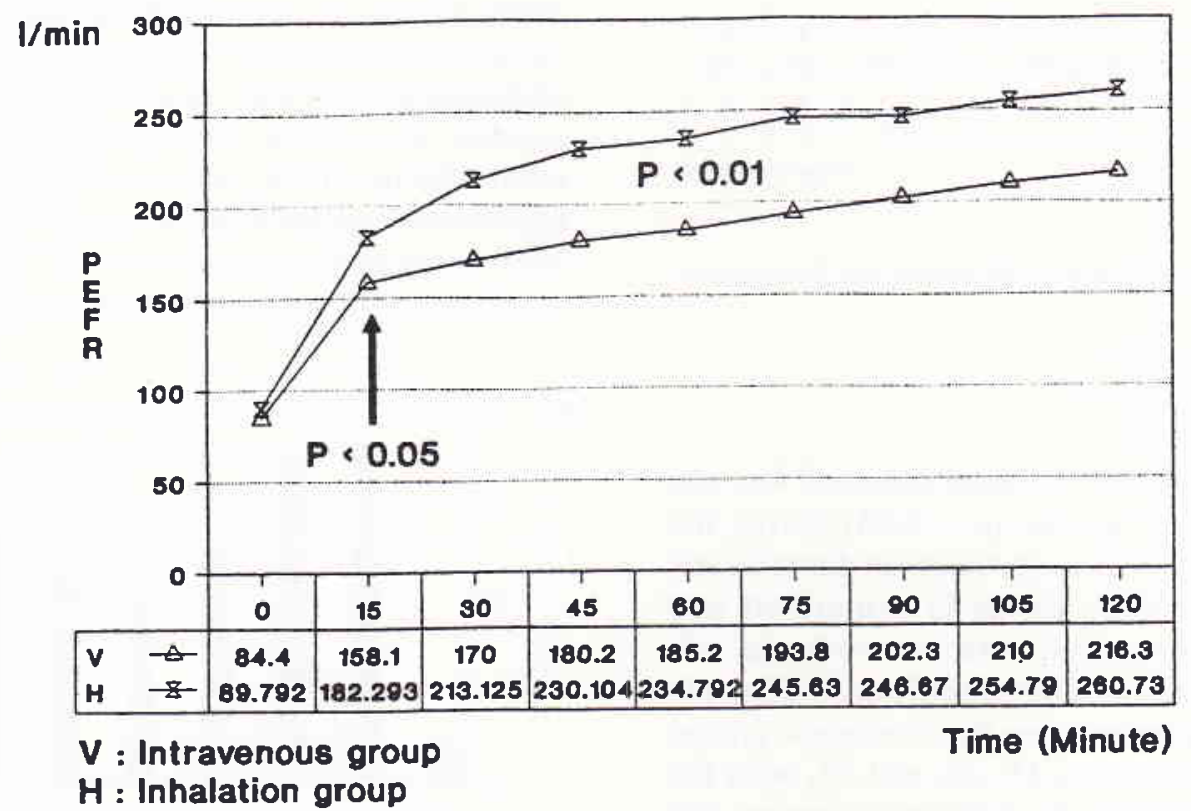

Figure 5. Comparison of mean PEFR between the inhalation and intravenous groups

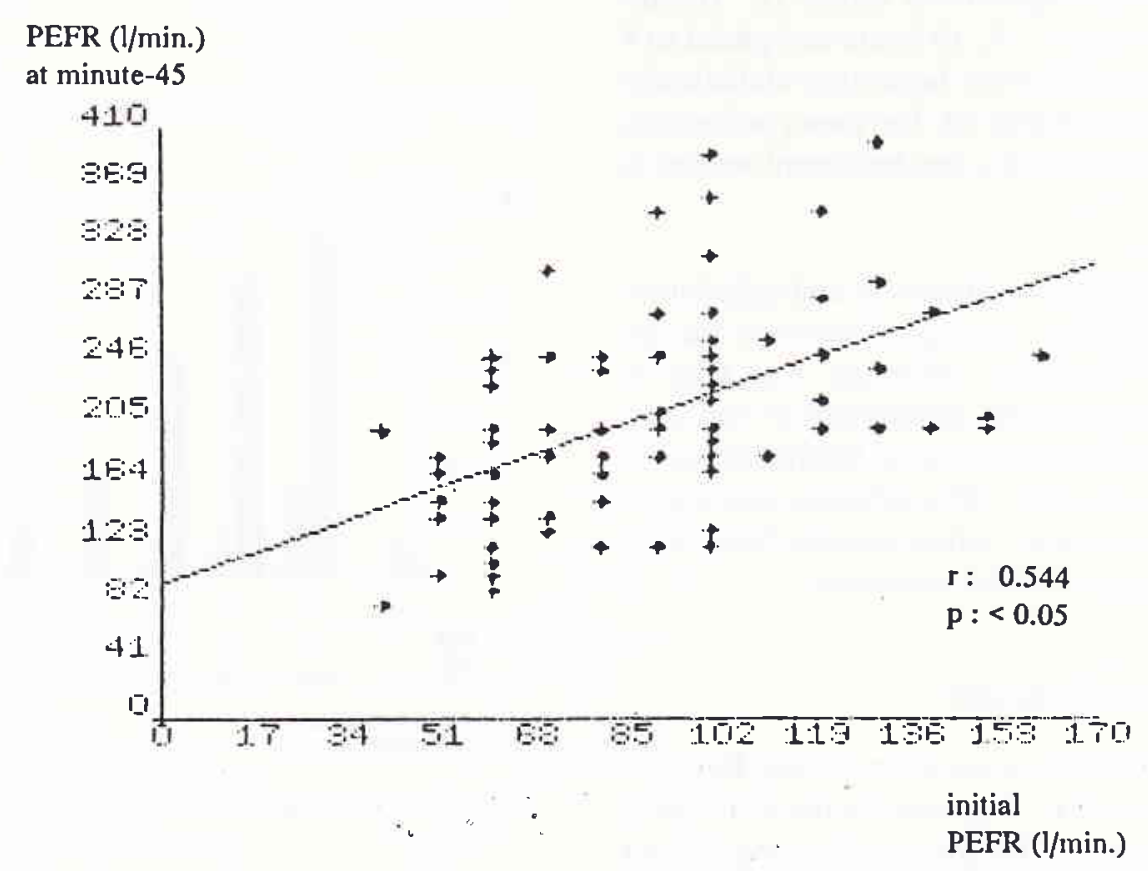

Figure 6. The correlation between initial obstruction and the improvement of lung function at minute 45. 
Table 4. Distribution of mean PEFR in \% of predictive value based on treatment group and duration of dyspnea before admisson

\begin{tabular}{clcc}
\hline & & \multicolumn{1}{c}{$\begin{array}{c}\text { Inhalation } \\
\text { Group }\end{array}$} & $\begin{array}{c}\text { Intravenous } \\
\text { Group }\end{array}$ \\
\cline { 3 - 4 } $\begin{array}{c}\text { Duration } \\
\text { of Dyspnea } \\
\text { (hour) }\end{array}$ & $\begin{array}{c}\text { Obscrvation } \\
\text { time (min.) }\end{array}$ & $\begin{array}{c}\text { PEFR } \\
\text { (\% of predicted) }\end{array}$ & $\begin{array}{c}\text { PEFR } \\
\text { (\% of predicted) }\end{array}$ \\
\hline $0-10$ & $(0)$ & 20.52 & 17.12 \\
& $(0-15)$ & 21.08 & 14.93 \\
& $(0-45)$ & 30.05 & 21.05 \\
$11-20$ & $(0)$ & 17.88 & 17.39 \\
& $(0-15)$ & 17.94 & 16.00 \\
& $(0-45)$ & 30.73 & 20.77 \\
$21-30$ & $(0)$ & & 20.08 \\
& $(0-15)$ & & 12.87 \\
& $(0-45)$ & & 19.32 \\
$>30$ & $(0)$ & & 22.44 \\
& $(0-15)$ & & 26.31 \\
& $(0-45)$ & & 27.22 \\
\hline
\end{tabular}

The patients were followed-up even after completion of the treatment. Of the 98 subjects treated in this study, $93(94.89 \%)$ were discharged with $81(82.65 \%)$ subjects having a score of 0 and the rest a score of 1 . The PEFR values were $270.81 \pm 60.94 \mathrm{l} / \mathrm{min}$. $(58.22 \pm$ $14.08 \%$ ) in the inhalation group and $247.3 \pm 36 \mathrm{l} / \mathrm{min}$. $(52.29 \pm 10.49 \%)$ in the intravenous group. The greatest improvement in PEFR was achieved in minute-60, the inhalation group achieved $51.04 \%$ of the predictive value and the intravenous group achieved $41 \%$ of the predictive value. Thirty six (36.73\%) patients had successfully overcome the acute asthmatic episode, achieving a PEFR value $50 \%$ of the predictive value.

\section{DISCUSSION}

It has been suggested that in patients with severe bronchial obstruction, mucus plugging of the airways might prevent nebulized sympathomimetics from having an effect on the peripheral airways and that intravenous infusions might therefore be more effective in these conditions. ${ }^{4,10}$ In this present study, however, the bronchodilating effects of inhaled salbutamol was found to be superior to intravenous salbutamol, irrespective of the baseline ventilatory function. This significant difference was apparent in minute-15, peaked in minute- 60 and lasted until minute- 90 .

During an acute asthmatic attack, even a slight degree of improvement needs a higher dose of inhaled B2- agonists. The airway obstruction leads to difficulty in inhaling and subsequently only a small percentage of the drug can be deposited in the airways. This condition is further aggravated by the increased diffusion barrier between the airway mucosa and the $\beta$ - receptors on the vessels walls and smooth muscle, and by the diminished responsiveness of the B2-receptors. ${ }^{11-13}$ Several studies have compared the efficacy of inhaled to intravenous B2- agonist. The results varied from slight superiority $(\mathrm{R}=5)$ of parenteral salbutamol, ${ }^{14,15}$ to equal effectiveness $(R=10)$ of both treatments, ${ }^{2,16}$ or slight or more marked superiority $(R=30)$ of inhaled salbutamol. ${ }^{4,5}$ The difference in results can be partly attributed to the inhaled to intravenous dose ratio (R) used and to the mode of administration.

The Swedish Society of Chest Medicine have found that $0.15 \mathrm{mg} / \mathrm{kgBW}$ is the threshold dose for inhaled salbutamol, since repetition of this dose caused systemic side-effects and high plasma levels of salbutamol. $^{5}$ The threshold dose for intravenous salbutamol was found to be $5 \mu \mathrm{g} / \mathrm{kgBW}$. It produced peak plasma concentration levels that was higher than that noted after the second inhaled dose. This peak plasma concentration of intravenous salbutamol appeared much sooner with a more rapid decline. Increasing the dose caused an increase in systemic side-effects. Although the inhalation dose was almost 30 that of the intravenous dose, Yanson have found that the average systemic availability of $0.15 \mathrm{mg} /$ $\mathrm{KgBW}$ of salbutamol was approximately egual to that of $5 \mu \mathrm{g} / \mathrm{kgBW}$ of intravenous salbutamol. ${ }^{17}$

B2-receptors are present in the airway smooth muscles, microvasculature, glands, and epithelial cells from the trachea to the terminal bronchioles. Their density increases with decreasing airway size. Both the central and the peripheral airways dilate after inhalation of B2-agonist drugs. The inhaled drug will be mainly centrally deposited. It not only exerts a local effect but will also be absorbed and distributed throughout the bronchial tree via the dense submucosal vascular network. ${ }^{13}$ Therefore the site of deposition of the $B$-agonists plays a less important role it is below the glottis. ${ }^{18,19}$ This process will depend on the inhalation maneuvres performed. A large amount of intrapulmonary deposited fraction (20-60\%) and a peak concentration of $35 \%$ was produced with deep and slow inspiration. ${ }^{8}$

Inhalations of large amounts of solution are time consuming and tiring for the patients, ${ }^{20}$ while a small amount or concentrated solution will decrease the nebulized fraction. ${ }^{9}$ Therefore the dose for inhaled 
salbutamol in this study was diluted to $2 \mathrm{ml}$. Several studies, however, have found that there was no correlation between the amount of solution and the increase of PEFR after inhalation. ${ }^{20,21}$ Intermittent inhalation through a fingertip controlled nebulizer used in this study permits a highly efficient and consistent method of delivery.

The duration of dyspnea prior to admission was not observed to be correlated with lung function changes in minutes- 60 and -120 for both treatment groups. But there was a moderate correlation $(r=0.54)$ between the severity of the initial obstruction and PEFR improvement in minute-45. Should the duration of dyspnea influenced the PEFR changes, it will not be apparent at the initial phase or the rapid phase of the biphasic response to treatment due to the resolution of the smooth muscle contraction. ${ }^{1,22}$ In addition, $22 \%$ of the cases in the intravenous group, with a duration of breathlessness of more than 21 hours, were patients with an acute episode of chronic asthma requiring intense treatment and longer periods of observation to relieve the mucosal airway inflammation.

Studies have showed that the increase in pulse rate were 19-24 beats/min. in intravenously treated groups compared with $5-8$ beats/min. in the inhalation groups. ${ }^{2,4,5,23}$ This study found that the increase was 19 beats/min. in intravenous group, which double that of the rate of 8 beats/min. for the inhalation group. Thos rise was significant in minutes-15 and -30 and declined in minute-45. Overall, the average pulse rate was significantly higher in the intravenously treated group.

The slight decrease of mean systolic and diastolic pressures in both groups were not found to be significant. This finding was not similar to the doubleblind randomized study using terbutalin, which showed a more significant decrease in mean blood pressure $(\mathrm{p}<0.02)$. $^{2}$ The side-effects, such as tremor, palpitation, and cephalgia were more prominent in the intravenously treated group. They can be attributed to hemodynamic changes caused by salbutamol stimulation of the $B 1$ and $B 2$ adrenergic receptors. Tremor and palpitations were marked in minutes -15 and -30 .

Previous studies have only included patients with an initial PEFR of $33 \%$ to the inhalation group and $31 \%$ the predictive value to the intravenous group. ${ }^{5}$ This present study have also included patients with an initial PEFR of less than $15 \%$ the predictive value, unless they could not be evaluated with a mini Wright ap- paratus. The average initial PEFR values in this study were $19.69 \%$ for the inhalation group and $18.18 \%$ the predictive value for the intravenous group. In the first hour of treatment, no significant increase in PEFR was found in 28 patients (56\%) of the intravenous group and 31 patients $(64.58 \%)$ of the inhalation group, whereas in 19 patients (38\%) of the intravenous and 15 patients $(31.85 \%)$ of the inhalation group the PEFR remained unchanged. There was a decline in the PEFR of 5 patients prior to aminophylline infusion. But there was a significant rise in PEFR after a bolus infusion of aminophylline was administered. It was unclear whether the rise in PEFR was due to aminophylline. The improvement in lung function by administration of corticosteroids was slow and not generally seen during the first 4 hours of treatment. Intravenous hydrocortisone restored 32 - adrenergic responsivity in 3-5 hours after administration (24). Early use of steroids is therefore indicated (25), since it can potentiate the effects of 12 -agonist drugs even though no effect was seen within the first 2 hours of treatment. Although the addition of aminophylline showed no immediate benefit, it can provide additional therapeutic benefit in the first 24 hours of patients with severe airway obstruction treated with systemic corticosteroids.

The patients improved enough to be discharged with a score of 0 or 1 and a PEFR of $58.24 \%$ the predictive value for the inhalation group and $51.58 \%$ of the predictive value for the intravenous group. The inhalation group had an increase of $51 \%$ in PEFR in minute60 , while in the intravenous group the rise was $41 \%$ of the predictive value. Thirty six (36.73\%) patients had passed the acute episode achieving a PEFR $50 \%$ of the predictive value. In a previous study only $35 \%$ of the cases had passed the acute episode in the first hour, even with intensive use of drugs of proven effectiveness.' The symptoms disappeared when the PEFR was $43 \%$ of the predictive value 22 and at $54 \%$ the predictive value, patients were scored as clinically free of symptoms. The results of physical examination was satisfactory, while lung function was still lower than normal. This was due to the tendency of the larger airways to increase their resistence quickly when stimulated, which can be reversed rapidly.

\section{CONCLUSIONS}

Intermittent inhalation of nebulized salbutamol was proven to be effective in relieving bronchospasm. The improvement of the clinical symptoms in severe acute asthmatic attacks was greater than when salbutamol 
was administered intravenously and the side-effects were minimal. Combining aminophylline to inhaled ß2-agonist can provide additive therapeutic benefits.

\section{Acknowledgements}

The authors wish to thank Dr. Armen Mochtar, of the Department of Pharmacology of the University of Indonesia, for his valuable advice on pharmacological and statistical aspects of this study.

\section{REFERENCES}

1. Fanta CH, Rossing TH, Mc Fadden ER. Emergency treatment treatment of asthma. Relationship among therapeutic combination, severity of obstruction and this course of response. Am J Med 1982; 72:416-22.

2. Van Renterghem $P$, Lamont $H$, Elinc W. Intravenous vs nebulized terbutalin in patients with acute severe asthma. A double blind randomized study. Ann Allergy 1987;59:313.

3. Hetzel MR, Clark TJH. Comparison of intravenous and aerosol salbutamol. Br Med J 1976; Oct: 919.

4. Bloomfield P, Carmichael J, Petrie GR. Comparison of given intravenously and by intermittent spontaneous pressure breathing in life threatening asthma. $\mathrm{Br}$ Med J 1979; 1: 848-50.

5. Swedish Society of Chest Medicine. High dose inhaled vs intravenous salbutamol combined with theophylline in severe acute asthma. Eur Respir J 1990; 3: 183-70.

6. Cochrane. Acute severe asthma. A colour atlas of asthma. England. Wolfe Medical Publication Ltd 1989: 70.

7. British Thoracic Society. Guideline for managment of asthma adults. Acute severe asthma. Br Med J 1990; 301: 797-301.

8. Matthys H, Kohler D. Pulmonary deposition of aerosols by different mechanical devices. Respiration 1985;48: 269-76.

9. Siez D, Chai H. A standard method of intermittent inlaled therapy via a jet nebulizer. Ann Allergy 1988; 57:245.

10. Cochrane GM. The role of bronchodilators in severe acute asthma in Clark TJH. Bronchodilator therapy. The basis of asthma and chronic obstructive airways disease management. New Zealand. Adis Press Lid 2nd ed; 1984: 167.
11. Clark TJH. Acute severe asthma. In Clark TJH, Godfrey S. London :2nd Chapman \& Hall 1983; 393.

12. Barnes P. Neural control of human airways in health and disease. State of art. Am Rev Respir Dis 1986; 134:1289

13. Kerreblyn PK. Beta agonists. In Kaliner MA, Bames PJ, Pierson eds: Asthma. New York. Marcel Dekker Inc; 1991:523.

14. Cheong B, Reynold S, Rajan KG. Comparison of intravenous with nebulized salbutamol in the treatment of acute severe asthma. Br Med J 1988; 297:448-50.

15. William S, Seaton A, Parrish R. Comparison of intravenous aminophylline and salbutamol in severe asthma. $\mathrm{Br}$ Med $\mathrm{J}$ 1975; Dec: 685.

16. Lawford P, Jones JM, Milledge JS. Comparison of intravenous and nebulized salbutamol in initial treatment of severe asthma. Br Med J 1978; 2: 84.

17. Yanson MJ. Plasma levels and effect of salbutamol after inhaled or i.v administration in stable asthma. Eur Respir $\mathrm{J}$ 1991; 4: 544-50.

18. Ruffin RE, Montgomery JM, Newhouse MT. Site of Badrenergik receptors in the respiratory tract. Delivery of fenoterol administration by two methods. Chest 1978:25680.

19. Kohler D, Fleischer W. Established facts in inhalation therapy. Arcis Verlag Munchen 1991.

20. Haldfield JW, Windenbank WJ, Bateman JRM. Is driving gas flow rate clinically important for nebulizer therapy?. Br J Dis of Chest 1988; 80:50-4.

21. Mitchel DM, Solomon MA, Tolfree SEJ, Short M, Spiro SG. Effect of particles size of bronchodilator aerosols on lung distribution and pulmonary function in patients with chronic asthma. Thorax 1987; 42: 457-61.

22. McFadden ER, Kiser R, DeGroot WJ. Acute bronchial asthma Relation between clinical and physiological manifestation. The N Engl J Med 1973; 288: 221-25.

23. Noseda A, Yernault JC. Sympathomimetics in acute severe asthma, inhaled or parenteral, nebulizer or spacer ? Eur Respir J 1989;2 : 377-82.

24. Holgate ST. Bronchoconstriction. In Clark TJH. Bronchodilator therapy. The basic of asthma and chronic obstructive airways disease managment. New Zealand. Adis Press Lid 1984; 1-13.

25. Littenberg B, Gluck EH. A controlled trial of methyl prednisolone in the emergency treatment of acute asthma. N Engl J Med 1986; 314: 150-52. 